\title{
Volcanic Fluxes Over the Last Millennium as Recorded in the Gv7 Ice Core (Northern Victoria Land, Antarctica)
}

\author{
Raffaello Nardin 1®, Alessandra Amore ${ }^{1}$, Silvia Becagli ${ }^{1}$, Laura Caiazzo ${ }^{2}$, Massimo Frezzotti ${ }^{3}$, \\ Mirko Severi ${ }^{1, *}{ }^{1}$, Barbara Stenni ${ }^{4}\left(\mathbb{D}\right.$ and Rita Traversi ${ }^{1}(\mathbb{C}$ \\ 1 Department of Chemistry "Ugo Schiff”, University of Florence, 50019 Florence, Italy; \\ raffaello.nardin@unifi.it (R.N.); ale.amore@gmail.com (A.A.); silvia.becagli@unifi.it (S.B.); \\ rita.traversi@unifi.it (R.T.) \\ 2 National Institute of Nuclear Physics (INFN), 50019 Florenc, Italy; laura.caiazzo@unifi.it \\ 3 Department of Sciences, Università degli Studi Roma Tre, 00146 Rome, Italy; massimo.frezzotti@uniroma3.it \\ 4 Department of Environmental Sciences, Informatics and Statistics, Ca' Foscari University of Venice, 30170 \\ Venezia Mestre, Italy; barbara.stenni@unive.it \\ * Correspondence: mirko.severi@unifi.it
}

Received: 15 November 2019; Accepted: 16 January 2020; Published: 20 January 2020

\begin{abstract}
Major explosive volcanic eruptions may significantly alter the global atmosphere for about 2-3 years. During that period, volcanic products (mainly $\mathrm{H}_{2} \mathrm{SO}_{4}$ ) with high residence time, stored in the stratosphere or, for shorter times, in the troposphere are gradually deposited onto polar ice caps. Antarctic snow may thus record acidic signals providing a history of past volcanic events. The high resolution sulphate concentration profile along a $197 \mathrm{~m}$ long ice core drilled at GV7 (Northern Victoria land) was obtained by Ion Chromatography on around 3500 discrete samples. The relatively high accumulation rate $\left(241 \pm 13 \mathrm{~mm}\right.$ we $\left.\mathrm{yr}^{-1}\right)$ and the 5-cm sampling resolution allowed a preliminary counted age scale. The obtained stratigraphy covers roughly the last millennium and 24 major volcanic eruptions were identified, dated, and tentatively ascribed to a source volcano. The deposition flux of volcanic sulphate was calculated for each signature and the results were compared with data from other Antarctic ice cores at regional and continental scale. Our results show that the regional variability is of the same order of magnitude as the continental one.
\end{abstract}

Keywords: volcanism; Antarctica; ion chromatography; paleoclimate; ice cores; tephra

\section{Introduction}

In recent years, several studies have been published investigating the correlation between volcanic activity and climate and environmental variability $[1,2]$. The effects of volcanic eruptions on climate are still unclear. Although some environmental parameters seem to be unaffected by explosive eruptions, there is a general consensus on their contribution to a cooling of the climate from regional to global scale. Two different kinds of compounds are emitted in the atmosphere in the aftermath of a volcanic eruption: the majority is comprised of magmatic material, emerging as solid particles (tephra) [2], the rest is comprised of different gases with $\mathrm{H}_{2} \mathrm{O}, \mathrm{CO}_{2}$, and $\mathrm{SO}_{2}$ being the most abundant.

The coarse magmatic material (essentially siliceous material) is much larger and heavier than the gaseous compounds and the particulate matter originated from gas-to-particle conversion. For this reason, the magmatic material is quickly removed from the atmosphere by settling (on the timescale of minutes to few weeks in the troposphere). As a result, these compounds have a very limited effect on the climate, except for areas in the immediate vicinity of the volcano [1]. In fact, due to the interaction with the infrared and visible radiation $[3,4]$, a rise in the temperatures can be observed in 
the region close to an erupting volcano. Among the gaseous compounds emitted during explosive eruptions, sulphur species are less soluble than the other compounds (i.e., $\mathrm{HCl}$ and other acidic species) and they can stay in the atmosphere for longer times. These compounds can thus be efficiently oxidized to $\mathrm{H}_{2} \mathrm{SO}_{4}$ in a short period of time [5] (within a month between the tropopause and $30 \mathrm{~km}$ of altitude [6]). In cases where $\mathrm{H}_{2} \mathrm{SO}_{4}$ is injected into the stratosphere, the atmospheric residence time of these compounds increases up to several years. In this circumstance, they can influence climate not only on a regional scale, but also on a global one. Such an effect is mainly represented by a surface cooling in the order of a tenth of a ${ }^{\circ} \mathrm{C}$, up to $1^{\circ} \mathrm{C}[4,7]$ as a result of the reflection of incoming solar radiation in the troposphere. This is due to the formation of clouds by the tropospheric $\mathrm{H}_{2} \mathrm{SO}_{4}$ acting as condensation nuclei. In order to better address the cause-effect relationship between volcanism and climate variations on different time scales, the paleo-volcanic record represents a key tool. In fact, thanks to tropospheric and stratospheric circulation pathways [8], sulphur compounds emitted in the atmosphere can reach the polar regions. Once delivered to polar areas and deposited in different forms (mainly acidic species) onto the ice sheets, the products of volcanic eruptions can provide a chemical signature of these events. The pioneer works by Hammer et al. [9-11] focused extensively on ice cores retrieved from Greenland. Since these studies, both electrochemical methods [9] and direct chemistry $[12,13]$ have been widely used in paleo-volcanic reconstructions. In this study, we present the volcanic record and accurate reconstruction of non-sea salt sulphate $\left(\mathrm{nssO}_{4}{ }^{2-}\right)$ deposition fluxes as recorded in an ice core drilled in GV7 (coastal East Antarctica). In our reconstruction we studied the volcanic events that occurred during the last millennium at a site with a relatively high accumulation rate $\left(241 \pm 13 \mathrm{~mm}\right.$ we $\left.\mathrm{yr}^{-1}\right)$. The 5 - $\mathrm{cm}$ sampling resolution of the ice core allowed the achievement of high temporal resolution stratigraphies of several chemical markers. Sulphate is considered to be the most reliable chemical marker of volcanic eruptions. Several methods have been used to measure sulphate or sulphur in ice cores: ion chromatography (IC) [14], fast ion chromatography (FIC) [15], and ICP-MS [16]. Using ion chromatography, we identified volcanic signals as concentration peaks of sulphate superimposed to a background that, in the Antarctic continent, is mainly of biogenic origin. The concentration profiles were used to calculate fluxes of volcanic sulphate at the drilling site. These volcanic fluxes were then compared with those from other three ice cores drilled in the same region (TALDICE, TD96, GV7-ITASE) calculated using the same method. Moreover, the volcanic fluxes calculated at GV7 were compared with all the available sulphate deposition flux datasets available for the Antarctic continent. Such reconstructions are a pivotal tool for the dating of the ice core itself and for the synchronization with other Antarctic ice cores. Moreover, our dataset represents a contribution to the already existing dataset of volcanic deposition fluxes for a comprehensive study of the volcanic activity-climate relationship.

\section{Materials and Methods}

GV7 drilling site $\left(70^{\circ} 41^{\prime} \mathrm{S}, 158^{\circ} 52^{\prime} \mathrm{E}\right.$; $1950 \mathrm{~m}$ a.s.l.; mean annual temperature $-31.8^{\circ} \mathrm{C}$ [17]) is located in coastal East Antarctica (Figure 1). This site has previously been investigated in the framework of the 2001/2002 ITASE traverse, when a 55-m firn core was retrieved. The snow accumulation rate was evaluated by using the 1965-1966 CE radioactive horizon associated to nuclear bomb tests [17-19]. The relatively high snow accumulation rate at the site $\left(241 \pm 13 \mathrm{~mm}\right.$ we $\mathrm{yr}^{-1}$ over the past 50 years [17-19], about 3-fold Talos Dome, 10-fold EPICA DC accumulation rates), the thickness of the ice (approx. $1700 \mathrm{~m}$ ), and the lack of post-depositional processes due to katabatic winds [17-19] make GV7 an ideal site to retrieve ice cores for paleoclimatic studies. Preliminary models based on the snow accumulation rate and the snow density at the site predicted that the upper 500 m may span back in time more than 2000 years. The expected time resolution was about $2 \mathrm{yr} \mathrm{m}^{-1}$ at the surface, $4 \mathrm{yr} \mathrm{m}^{-1}$ at $50 \mathrm{~m}$, and $6 \mathrm{yr} \mathrm{m}^{-1}$ at $500 \mathrm{~m}$ [20]. The drilling operations were carried out during the 2013/2014 Antarctic summer using an electromechanical drilling system (Eclipse Ice drill Instrument) which was able to extract a $247.2 \mathrm{~m}$ long core from the bottom of a snow pit down to a depth of $250.7 \mathrm{~m}$. 
The ice core was logged and cut in $60 \mathrm{~cm}$ long sections directly in the field, and these sections were stored at $-25^{\circ} \mathrm{C}$ and shipped to EUROCOLD lab (University of Milan Bicocca, Italy) and shared among different research groups after a longitudinal cut. The sections of GV7 ice core for ionic content analysis were sealed in plastic bags and stored at $-25^{\circ} \mathrm{C}$ in the cold room of the University of Florence. Each core section was manually decontaminated in the cold room under a class 1000 laminar flow hood using ceramic knives. After decontamination the core sections were cut in subsamples with a resolution of about $5.0 \mathrm{~cm}$. The subsamples were then stored in precleaned polystyrene vials and melted just before the ion chromatographic analysis. The ice core sections that were too small to be handled were stored in precleaned plastic containers and decontaminated through three consecutive soakings in UHQ water shortly before the analysis. The ion chromatographic analysis allowed obtaining the depth profiles of several trace elements. Two Ion Chromatographs were simultaneously used for the analysis: a Thermo Dionex ICS-1000 for the determination of the cationic content $\left(\mathrm{Li}^{+}, \mathrm{Na}^{+}, \mathrm{NH}_{4}{ }^{+}, \mathrm{K}^{+}\right.$, $\left.\mathrm{Mg}^{2+}, \mathrm{Ca}^{2+}\right)$ and Thermo Dionex DX-500 equipped with a GP50 gradient pump for anionic content $\left(\mathrm{F}^{-}\right.$, Formate, methanesulfonate $\left(\mathrm{MS}^{-}\right), \mathrm{Cl}^{-}, \mathrm{NO}_{3}{ }^{-}, \mathrm{SO}_{4}{ }^{2-}$ ). Further details about the columns used and the daily calibration procedures for each ion chromatographic system are described in detail elsewhere [21,22]. The analytical performances of the method and the mean sulphate concentrations in EDC96 and GV7 are reported in Tables S1 and S2. Samples, blanks, and standards solutions were injected through an auto-sampler (222XL Liquid Handler, Gilson (Middleton, WI, USA)) with a single needle to minimize any possible contamination.

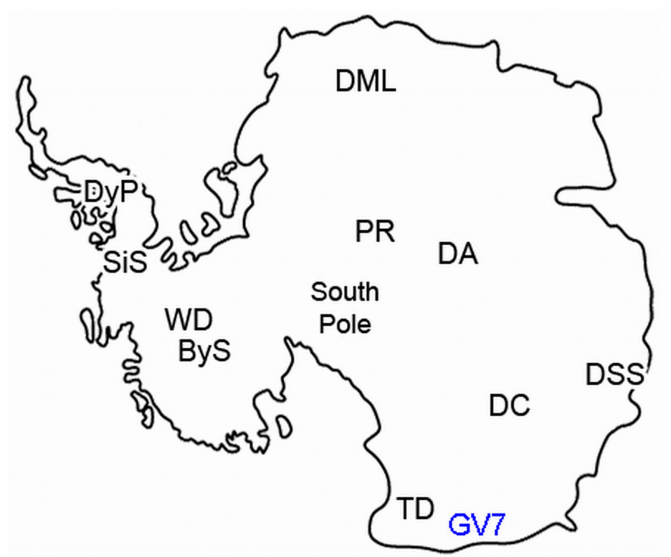

Figure 1. Map of Antarctica (1:24,000,000) showing the GV7 site (blue) and the position of other main drilling sites used to compare volcanic fluxes (DML: Dronning Maud Land; DyP: Dyer Plateau; SiS: Siple Station; WD: WAIS Divide; ByS: Byrd Station; PR: Plateau Remote; DA: Dome A; DC: Dome C; DSS: Law Dome; TD: Talos Dome).

For the identification of the volcanic peaks (and in the following calculation of volcanic deposition fluxes), one of the critical steps is the correct assessment of non-volcanic (e.g., biogenic sulphate) contribution to sulphate. In fact, due to seasonality of its precursor's sources, biogenic sulphate is characterized by a recurring pattern with summer maxima [23-25], making it useful for dating by annual layer counting in sites with sufficiently high snow accumulation rate [18,19]. Therefore, distinguishing between a sulphate peak due to volcanic deposition and a summer maximum is not always straightforward, especially for small volcanic signatures. Such a discrimination also depends on the glaciological features of the sampling site, namely extent and timing of snowfalls.

In this work, in order to distinguish between concentration enhancements of non-sea salt sulphate $\left(\mathrm{nssSO}_{4}{ }^{2-}\right.$ ) due to volcanic deposition or biogenic inputs, we used two different methods. In both cases, a biogenic background and a statistical threshold over which each point (i.e., the concentration of a given ice sample) was considered as belonging to a volcanic signature were calculated.

In the first method, we followed the procedure chosen by Castellano et al. and other authors [26-28] as described here. Firstly, those sample points for which the $\mathrm{nsSO}_{4}{ }^{2-}$ concentration was above the 
95th percentile (i.e., spikes due to external contamination and volcanic peaks) were discarded and a new dataset (Corrected DataSet, hence called CDS) was created. This was necessary in order to remove both volcanic contribution and possible external contamination not to affect the estimate of the biogenic background.

The biogenic background contribution to non-sea salt sulphate concentration at each point was then estimated by calculating the running mean in a 101-point sample array along the CDS and centered on the studied point. The choice of the width of this array was somewhat empirical, but a 101-point sample, roughly corresponding to a 30-year span in most part of the ice core, was found to be a good compromise between the short-term and long-term variability of biogenic background. Indeed, picking up a longer time frame would have smoothed excessively the inter-annual variability of biogenic nssSO ${ }_{4}{ }^{2-}$; instead a shorter time frame would have produced very high noise and would have been affected too much by single-year variability in summer-to-winter shifts.

The standard deviation (SD) of the biogenic background calculated in this way was then used to establish different thresholds for highlighting volcanic signatures, by adding two times and three times the SD to the biogenic background.

A sample point was considered part of a volcanic peak if it exceeded the 2SD threshold (running mean $+2 S D$ ) and if at least one of the surrounding points was above the 3SD (running mean $+3 S D$ ). This was found to be the most restrictive method of discriminating non-volcanic peaks from the biogenic background and made it possible to identify a relatively low number of volcanic signatures.

Another method, also reported in the literature $[29,30]$, was used in this work and its results were compared to the one already described. Firstly, the biogenic background was estimated by calculating the running median over an interval of 101 sample points (the choice of the interval relies upon the considerations mentioned earlier). The use of the median instead of the mean value made it possible to use the whole raw dataset and not the CDS (Corrected Data Set) as previously done. A threshold equal to the sum of biogenic background and the median of absolute deviations (MAD) of the biogenic background (multiplied by three) was then calculated for all the sample points. As compared to the one previously described, this method was found to be less selective, detecting a larger number of possible volcanic peaks with respect to the previous one. Therefore, we combined the two detecting methods in order to select more reliably only the peaks more likely to be of volcanic origin. We chose to ascribe a sulphate peak to a volcanic source only if the two following requirements were met: (1) two consecutive points were above the RMN + 2SD threshold, (2) both the RMN + 3SD and the RMA + 3MAD thresholds were exceeded at the same time.

The amount of volcanic sulphate (i.e., volcanic flux, $\boldsymbol{f}$ ) was calculated as mass of sulphate deposited onto a defined snow surface area $\left(\mathrm{kg} / \mathrm{km}^{2}\right)$ according to the following procedure. The total non-sea salt sulphate flux was calculated by integrating the non-sea salt sulphate concentration of all the samples within the depth interval corresponding to a 10-year span (centered on the year corresponding to the $\mathrm{nssSO}_{4}{ }^{2-}$ maximum). From this total amount of nss- $\mathrm{SO}_{4}{ }^{2-}$ we subtracted the biogenic background calculated as the integral in the 10-year span of the $\mathrm{nsSO}_{4}{ }^{2-}$ calculated in the same time frame.

The temporal width within which the $f$ was calculated is a critical step in this kind of reconstruction, being unavoidably affected by discretional choice upon knowledge and previous experience on volcanic signatures from ice cores $[26,27,31,32]$. The temporal frame chosen here was found to be a good compromise between the need of evaluating the volcanic fluxes without any loss and a way to consider the seasonal variations of the biogenic levels of $\mathrm{nsSO}_{4}{ }^{2-}$.

By taking into account the depth interval corresponding to the 10-yr frame, the snow/ice density conversion factor and the thinning function of the ice, the $f$ as $\mathrm{kg} / \mathrm{km}^{2}$ of $\mathrm{nssSO}_{4}{ }^{2-}$ was calculated. Using the same methodological approach we have detected the volcanic signatures and calculated the corresponding volcanic fluxes in three other ice cores retrieved from near drilling sites: GV7

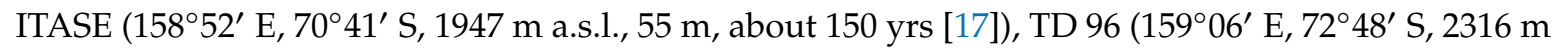
a.s.l., $89 \mathrm{~m}$, about 800 yrs [18]), and TALDICE $\left(159^{\circ} 11^{\prime} \mathrm{E}, 72^{\circ} 49^{\prime} \mathrm{S}, 2315 \mathrm{~m}\right.$ a.s.1., $1620 \mathrm{~m}$, more than 
200,000 yrs [32]). The datasets used to detect volcanic peaks and to calculate their fluxes in GV7 ITASE, TD 96, and TALDICE are those used in their publications, respectively $[17,18]$ and [32].

\section{Results and Discussion}

\subsection{Ice Core Dating and Peaks Assessment}

Following these two methods, we identified 24 peaks that are significantly different from the marine biogenic background. After a preliminary counting of the annual layers, we used the volcanic spikes to adjust the age scale by comparing the age of each peak with the volcanic events listed in literature [30,33]. A preliminary depth vs. age curve is shown in Figure S1.

The double peak found between 11.05 and $11.32 \mathrm{~m}$ was attributed to the well-known and already documented Pinatubo volcanic eruption [28,30,34-36] and was consequently dated to 1992 (the Pinatubo explosive eruption occurred in June 1991, but its volcanic aerosol was dispersed in the atmosphere covering a period from early/mid 1992 CE to mid 1994 [28]). The double peak pattern of this signature can be explained by two different eruptions occurring very close in time. Cerro Hudson (southern Chile) explosive eruption occurred in August 1991 and due to its proximity to Antarctica compared to the Pinatubo (Philippines), its emissions entered the polar atmosphere before the arrival of the latter [37,38]. For this reason, the peak found between 11.05 and $11.20 \mathrm{~m}$ depth was attributed to Pinatubo and the one between 11.20 and $11.32 \mathrm{~m}$ to Mt. Cerro Hudson. Since the two eruptions occurred almost simultaneously (about two months), one would not expect to distinguish the two events from stratigraphic records. In the GV7 sulphate record, it is possible to highlight two close but separate signatures thanks to the relatively high accumulation rate at this site and high analysis resolution.

The fine structure of the peak shape depends on extent of sulphate deposition, deposition mechanisms (dry/wet deposition), glaciological features as accumulation rate, preservation of an undisturbed stratigraphy, and analysis resolution. Only the favorable combination of these many variables makes it possible to spot close eruptions as distinct signals [39-41].

The peaks found between 22.02 and $22.62 \mathrm{~m}$ depth were both attributed to the well-known and already documented [29,30] volcanic eruption of the Agung volcano (Indonesia). This attribution is consistent with the signature of Pinatubo previously established, on the basis of annual layer counting. The two peaks were hence dated $1964 \mathrm{CE}$ and $1965 \mathrm{CE}$. This two-peaks pattern for the Agung eruption is not easily explained, but a possible reason could be a snow reworking operated by the wind at the drilling site.

The volcanic signature between 49.22 and $49.48 \mathrm{~m}$ was found to be consistent with the Krakatau explosive eruption. This volcanic event was found in ice cores drilled both in Antarctica and Greenland [28-30,42] and it represents one of the most important horizons in ice core dating. The eruption occurred in $1883 \mathrm{CE}$ and this date is compatible with the 1884 attributed to the highest peak found at $49.35 \mathrm{~m}$ depth with the deposition of volcanic aerosol ending in the $1886 \mathrm{CE}$.

Between 55.49 and $63.55 \mathrm{~m}$ two peaks can be observed, and they are consistent with the Makian and the Cosiguina volcanic eruptions found in other ice cores $[29,30]$ and to these peaks we attributed the 1863 CE and 1836 CE dates, respectively.

The two peaks found between 68.52 and $70.58 \mathrm{~m}$ depth constitute one of the most recognizable "doublets" found in many ice cores and are ascribed to two of the major volcanic signatures of the last millennium recorded in ice cores. The date of $1816 \mathrm{CE}$ was attributed to the highest of the two peaks $(68.75 \mathrm{~m})$ and is related to the explosive eruption of the Tambora volcano in the Indonesian island of Rakata. The nearest peak, at $70.53 \mathrm{~m}$, despite not being documented in historical archives, is likely due to an already known volcanic explosive eruption [30,42-44]. It was dated $1809 \mathrm{CE}$ and it was consistent with the annual counting of the seasonal $\mathrm{nsSO}_{4}{ }^{2-}$. 
The three consecutive peaks found at 101.25, 108.39, and $117.48 \mathrm{~m}$ depth were found to be consistent with the volcanic eruptions of the Gamkonora, Parker Peak, and Huaynaputina already identified in several other ice cores. To these events were assigned ages of $1673 \mathrm{CE}, 1642 \mathrm{CE}$, and 1600 CE, respectively.

Another temporal horizon detected here and characterized is the one found at a depth of 145.41 $\mathrm{m}$, assigned to the $1458 \mathrm{CE}$ eruption. This volcanic event has long been thought to originate from the Kuwae caldera in Vanuatu [29-32], but very recently this attribution has been dismissed by using cryptotephra analysis on the SPICEcore [45]. The most probable candidate for this eruption recorded in Antarctic ice cores is Mount Reclus in Chile [45].

The peak found at $181.86 \mathrm{~m}$ was ascribed to the Samalas eruption and we assigned the age 1260 $\mathrm{CE}$ to the depth corresponding to the maximum $\mathrm{nsSO}_{4}{ }^{2-}$ concentration. The eruption itself is dated $1257 \mathrm{CE}$ [46], but the volcanic sulphate deposition occurred in a 2-3 year time interval [30]. This age is consistent with the spike in $\mathrm{nsSOO}_{4}{ }^{2-}$ concentration at a depth of $183.07 \mathrm{~m}$, where traces of volcanic materials (tephra) were visible to the naked eye. Such a tephra layer was already observed and accurately dated in ice [32,47] and marine cores [48] and was recently attributed to the eruption of Mount Rittmann that occurred in 1254, according to Narcisi et al. [47], or in $1252 \pm 2$ according to Lee et al. [49].

The complete list of the known volcanoes found in the $\mathrm{nsSO}_{4}{ }^{2-}$ profile, their location, type, and altitude are reported in Table 1, while the $\mathrm{nsSO}_{4}{ }^{2-}$ concentration throughout the whole ice core and the volcanic signatures are reported in Figure 2.

Table 1. Known volcanic signatures found in the GV7 ice core, their depth, eruption date, location, coordinates, and elevation are also reported. For details about single volcanoes we recommend visiting https://volcano.si.edu/list_volcano_holocene.cfm.

\begin{tabular}{|c|c|c|c|c|c|c|c|}
\hline Volcano & Depth (m) & $\begin{array}{l}\text { Eruption } \\
\text { (year CE) }\end{array}$ & Location & Lat. & Long. & Elevation & Type \\
\hline Pinatubo & 11.10 & 1991 & $\begin{array}{c}\text { Luzon, } \\
\text { Philippine }\end{array}$ & $15^{\circ} 07^{\prime} \mathrm{N}$ & $120^{\circ} 21^{\prime} \mathrm{E}$ & $1741 \mathrm{~m}$ & Stratovolcano \\
\hline Cerro Hudson & 11.26 & 1991 & Chile & $45^{\circ} 54^{\prime} \mathrm{S}$ & $75^{\circ} 58^{\prime} \mathrm{W}$ & $1905 \mathrm{~m}$ & Stratovolcano \\
\hline Agung & 22.12 & 1963 & Bali & $8^{\circ} 20^{\prime} \mathrm{S}$ & $115^{\circ} 30^{\prime} \mathrm{E}$ & $3142 \mathrm{~m}$ & Stratovolcano \\
\hline Krakatau & 49.35 & 1883 & Indonesia & $6^{\circ} 06^{\prime} \mathrm{S}$ & $105^{\circ} 25^{\prime} \mathrm{E}$ & $813 \mathrm{~m}$ & Caldera \\
\hline Tambora & 68.75 & 1815 & Indonesia & $8^{\circ} 15^{\prime} \mathrm{S}$ & $118^{\circ} 0^{\prime} \mathrm{E}$ & $2850 \mathrm{~m}$ & Stratovolcano \\
\hline Gamkonora & 101.25 & 1673 & Halmahera & $1^{\circ} 22^{\prime} \mathrm{N}$ & $127^{\circ} 32^{\prime} \mathrm{E}$ & $1560 \mathrm{~m}$ & Stratovolcano \\
\hline Parker Peak & 108.39 & 1640 & Philippines & $6^{\circ} 11^{\prime} \mathrm{N}$ & $124^{\circ} 89^{\prime} \mathrm{E}$ & $1824 \mathrm{~m}$ & Stratovolcano \\
\hline Huaynaputina & 117.48 & 1600 & Perú & $16^{\circ} 36^{\prime} \mathrm{S}$ & $70^{\circ} 51^{\prime} \mathrm{W}$ & $4850 \mathrm{~m}$ & Stratovolcano \\
\hline Reclus & 145.41 & 1458 & Chile & $50^{\circ} 57^{\prime} \mathrm{S}$ & $73^{\circ} 35^{\prime} \mathrm{W}$ & $-2 \mathrm{~m}$ & $\begin{array}{l}\text { Pyroclastic } \\
\text { cone }\end{array}$ \\
\hline
\end{tabular}



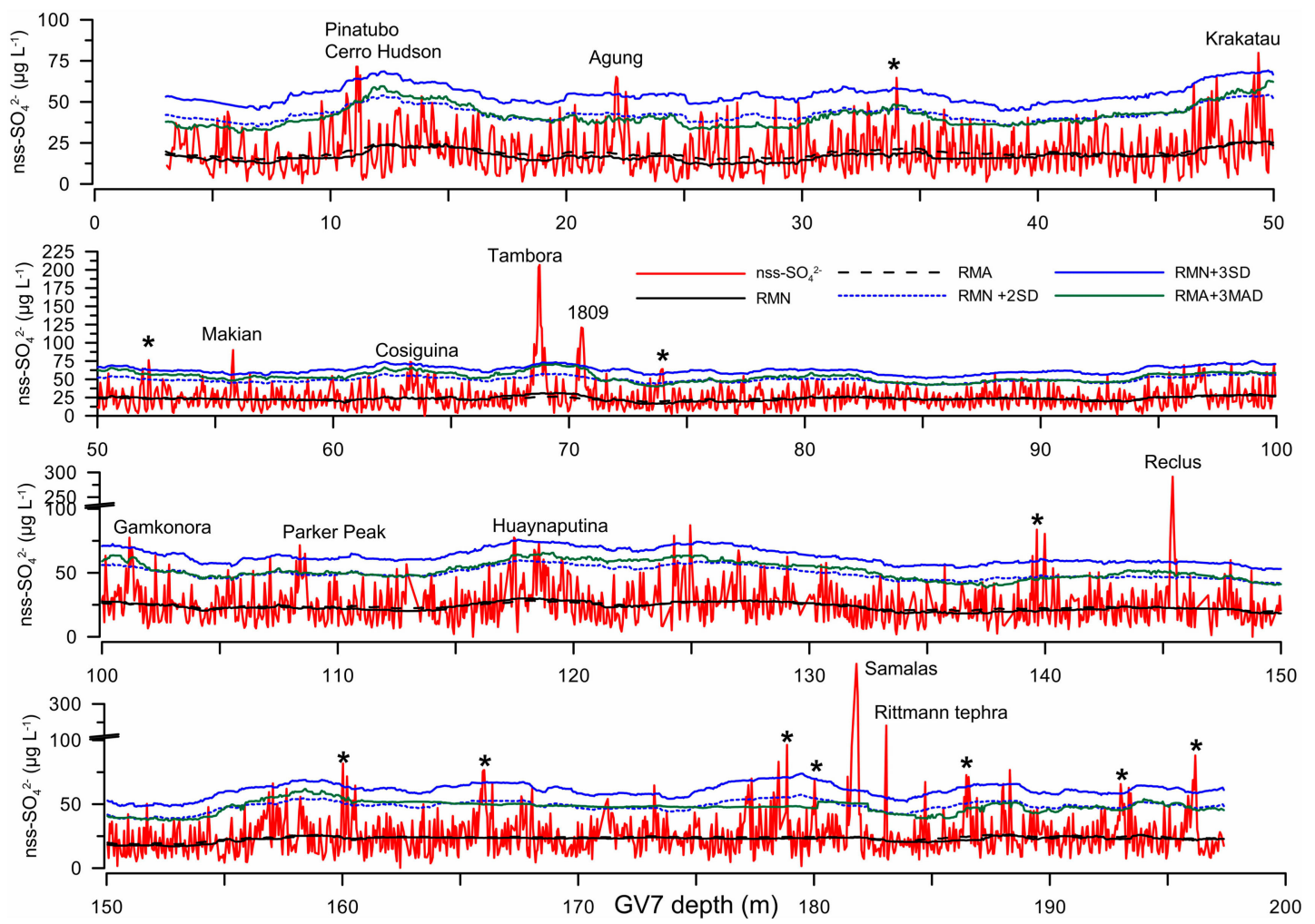

Figure 2. Non-sea salt sulphate concentration profiles and thresholds used in the identification of volcanic signatures (RMN: running mean; SD: standard deviation; RMA: running median; MAD: median absolute deviation). The names of known volcanoes are shown above each peak, the symbol * marks unknown events detected as probable volcanic eruptions.

\subsection{Volcanic Fluxes}

The volcanic fluxes calculated as above described for the major signatures found in the GV7 ice core are reported in Table 2. For historically known eruptions, the VEI (Volcanic Explosive Index [50]) is also reported [33]. It should be noted that for minor eruptions (VEI $<3$ ), the tropical circulation belt prevents the long-range inter-hemispheric transport of volcanic material [11], with the exception of $\mathrm{CO}_{2}$ and other gaseous compounds that have a longer atmospheric residence time. Thus, middle and high northern latitude eruptions seem to have little to no effect on the Antarctic regions [51] so that only those eruptions occurring between $20^{\circ} \mathrm{N}$ and $20^{\circ} \mathrm{S}$ could affect both hemispheres. However, it is also possible to find high latitude eruptions in Antarctic ice, as shown by Koffman et al. [52], reporting the Puyehue-Cordón Caulle tephra from Chile at WAIS Divide within a few weeks of the eruption. Another example is described by Dunbar et al. [53], showing a tephra found at WAIS Divide and originated by Oruanui supereruption (New Zealand) during LGM. In this case the authors modeled a tropospheric transport time shorter than 2 weeks.

The coordinates of the known volcanoes found in the GV7 core are reported in Table 1. Most of the observed volcanic signatures were attributed to volcanoes in the Southern hemisphere. The lack of historical records in these regions makes it sometimes difficult or even impossible to identify the source of the eruption. For this reason, some of the volcanic signatures listed in Table 2 are attributed to unknown volcanoes. The geographical location of the different volcanoes could also be the reason why in some cases, volcanic eruption characterized by a higher VEI are responsible for a lower sulphate flux in the studied Antarctic sites (e.g., Krakatau, Huaynaputina). 
Table 2. Volcanic signatures and volcanic fluxes (in $\mathrm{kg} / \mathrm{km}^{2}$ ) found in GV7, GV7 (ITASE), Talos Dome, and TALDICE ice cores and comparison with the Volcanic Explosive Index (VEI) of the known volcanic eruption. The uncertainty of flux $(\sigma)$, calculated as the standard deviation of the biogenic flux evaluated by MAD, is also reported for the GV7 core. " $x$ " marks the signatures showing two consecutive data points of non-sea salt sulphate $\left(\mathrm{nsSO}_{4}{ }^{2-}\right.$ ) concentration values above the corresponding threshold. The flux of Pinatubo and Cerro Hudson volcanic signatures was calculated as the sum of both, due to the closeness and partial/total overlap of the peaks.

\begin{tabular}{|c|c|c|c|c|c|c|c|c|c|c|}
\hline \multirow[b]{2}{*}{ Depth (m) } & \multirow[b]{2}{*}{ Volcano } & \multirow[b]{2}{*}{$2 \sigma$} & \multirow[b]{2}{*}{$3 \sigma$} & \multirow[b]{2}{*}{ 3MAD } & \multicolumn{4}{|c|}{ Volcanic Fluxes } & \multirow[b]{2}{*}{$\sigma$} & \multirow[b]{2}{*}{ VEI } \\
\hline & & & & & $\begin{array}{c}\text { GV7 } \\
\text { ITASE }\end{array}$ & TD96 & TALDICE & GV7 & & \\
\hline 11.10 & $\begin{array}{c}\text { Pinatubo } \\
\text { Cerro Hudson }\end{array}$ & $x$ & $\mathrm{x}$ & $x$ & 10.46 & 4.28 & - & 5.28 & 2.88 & 6 \\
\hline 22.12 & Agung & $x$ & $x$ & $x$ & 8.15 & 5.07 & $*$ & 5.29 & 0.61 & 4 \\
\hline 34.01 & Unknown & $x$ & & $x$ & 2.03 & $<2$ & - & 3.47 & 0.49 & \\
\hline 49.35 & Krakatau & $x$ & & $\mathrm{x}$ & 11.51 & 7.99 & 10.20 & 8.06 & 0.56 & 6 \\
\hline 52.17 & Unknown & $x$ & & $x$ & $<2$ & - & - & 6.58 & 0.62 & \\
\hline 55.75 & Makian & $x$ & $x$ & $x$ & $<2$ & 5.51 & 2.51 & 6.21 & 0.50 & 4 \\
\hline 63.27 & Cosiguina & $x$ & $x$ & $x$ & & 11.90 & 6.39 & 15.55 & 0.47 & 5 \\
\hline 68.75 & Tambora & $x$ & $x$ & $x$ & & 42.31 & 34.44 & 41.12 & 0.97 & 7 \\
\hline 70.53 & $\begin{array}{c}\text { Unknown } \\
1809\end{array}$ & $x$ & $\mathrm{x}$ & $\mathrm{x}$ & & 44.46 & 38.32 & 23.32 & 1.66 & $?$ \\
\hline 73.97 & Unknown & $x$ & $x$ & $x$ & & 8.52 & 5.08 & 6.09 & 0.75 & \\
\hline 101.25 & Gamkonora & $x$ & & $x$ & & $\begin{array}{l}\text { Missing } \\
\text { data }\end{array}$ & - & 12.91 & 0.48 & 5 \\
\hline 108.39 & Parker Peak & $x$ & & $x$ & & 6.43 & 8.56 & 11.14 & 0.58 & $?$ \\
\hline 117.48 & Huaynaputina & $x$ & $x$ & $x$ & & 11.25 & 8.23 & 8.77 & 0.94 & 6 \\
\hline 139.99 & Unknown & $x$ & & $\mathrm{x}$ & & - & 2.26 & 5.30 & 0.28 & \\
\hline 145.41 & Reclus & $x$ & $x$ & $x$ & & 119.7 & 22.66 & 28.13 & 0.42 & 6 \\
\hline 160.25 & Unknown & $x$ & $x$ & $x$ & & 16.43 & 13.27 & 12.12 & 0.69 & \\
\hline 166.01 & Unknown & $x$ & $x$ & $x$ & & 15.22 & 13.71 & 16.69 & 0.09 & \\
\hline 178.73 & Unknown & $x$ & $x$ & $x$ & & 3.55 & 41.51 & 38.84 & 0.14 & \\
\hline 180.03 & Unknown & $x$ & $x$ & & & 10.23 & 9.38 & 8.09 & 0.11 & \\
\hline 181.86 & Samalas & $x$ & $x$ & $x$ & & 21.72 & 121.51 & 53.36 & 1.01 & 7 \\
\hline 186.60 & Unknown & $x$ & $x$ & $x$ & & 12.68 & 23.06 & 10.98 & 0.67 & \\
\hline 188.03 & Unknown & $x$ & & $x$ & & $<2$ & $<2$ & $<2$ & 0.40 & \\
\hline 193.07 & Unknown & $x$ & $x$ & $x$ & & & 10.86 & 10.99 & 0.66 & \\
\hline 196.17 & Unknown & $x$ & $x$ & $x$ & & & 8.95 & 8.15 & 0.29 & \\
\hline
\end{tabular}

The volcanic fluxes calculated in this work for the ice cores reported in Table 2 were also compared to the ones reported in literature from ice cores drilled from different sites in the Antarctic continent (see Table 3 and Figure 1 for ice core locations) and the complete list of volcanic fluxes is shown in Table 4, together with the uncertainty of the estimate, where reported.

Table 3. Antarctic ice cores used in the comparison of volcanic fluxes and corresponding geographical coordinates.

\begin{tabular}{|c|c|c|}
\hline Site & Abbr. & Position \\
\hline Talos Dome & (TD) & $72^{\circ} 48^{\prime} \mathrm{S} ; 159^{\circ} 06^{\prime} \mathrm{E}$ \\
\hline Dome C [26] & (DC) & $75^{\circ} 06^{\prime} \mathrm{S} ; 123^{\circ} 24^{\prime} \mathrm{E}$ \\
\hline WAIS Divide [30] & (WD) & $79^{\circ} 47^{\prime} \mathrm{S} ; 112^{\circ} 09^{\prime} \mathrm{W}$ \\
\hline Dome South Summit (Law Dome) [54] & (DSS) & $66^{\circ} 43^{\prime} \mathrm{S} ; 112^{\circ} 48^{\prime} \mathrm{E}$ \\
\hline Siple Station [55] & $(\mathrm{SiS})$ & $75^{\circ} 55^{\prime} \mathrm{S} ; 84^{\circ} 15^{\prime} \mathrm{W}$ \\
\hline Dyer Plateau [55] & (DyP) & $70^{\circ} 40^{\prime} \mathrm{S} ; 64^{\circ} 52^{\prime} \mathrm{W}$ \\
\hline South Pole [56] & (PS14) & $90^{\circ} \mathrm{S}$ \\
\hline South Pole [56] & (PS1) & $90^{\circ} \mathrm{S}$ \\
\hline \multirow{4}{*}{ Dronning Maud Land [29] } & (DML05) & approx. $75^{\circ} 00^{\prime} \mathrm{S} ; 00^{\circ} 00^{\prime} \mathrm{E}$ \\
\hline & (DML07) & approx. $75^{\circ} 30^{\prime} \mathrm{S} ; 04^{\circ} 00^{\prime} \mathrm{W}$ \\
\hline & (DML17) & approx. $75^{\circ} 10^{\prime} \mathrm{S} ; 07^{\circ} 00^{\prime} \mathrm{E}$ \\
\hline & (DML03) & approx. $74^{\circ} 30^{\prime} \mathrm{S} ; 03^{\circ} 00^{\prime} \mathrm{E}$ \\
\hline
\end{tabular}


Table 3. Cont.

\begin{tabular}{ccc}
\hline Site & Abbr. & Position \\
\hline Amundsen-Scott, South Pole [57] & $(\mathrm{SP} 1)$ & $90^{\circ} \mathrm{S}$ \\
Amundsen-Scott, South Pole [58] & $(\mathrm{SP} 2)$ & $89^{\circ} 57.5^{\prime} \mathrm{S} ; 17^{\circ} 40^{\prime} \mathrm{W}$ \\
Dome A [59] & $(\mathrm{DA})$ & $80^{\circ} 22^{\prime} \mathrm{S} ; 77^{\circ} 22^{\prime} \mathrm{E}$ \\
Plateau Remote [60] & $(\mathrm{PR})$ & $84^{\circ} 00^{\prime} \mathrm{S} ; 43^{\circ} 00^{\prime} \mathrm{E}$ \\
Byrd Station [61] & $(\mathrm{ByS})$ & $80^{\circ} 01^{\prime} \mathrm{S} ; 119^{\circ} 31^{\prime} \mathrm{W}$ \\
\hline
\end{tabular}

In addition to single drilling sites, a composite of multiple ice cores evaluated by Sigl [35] is also reported in Table 4 (named "Ant. comp.") as the average volcanic sulphate deposition in Antarctica, for moderate and large events $\left(>5 \mathrm{~kg} / \mathrm{km}^{2}\right)$. In order to better appreciate the comparison of the volcanic fluxes recorded at GV7 with the available data from the whole Antarctic continent, our results are displayed as boxplots (Figure 3). The colored box contains 50\% of the data with the inner line showing the median value, while the bottom and top lines represent the minimum and maximum values, respectively.

Most of the volcanic fluxes found in this work stand between the 25th and 75th percentile (seven out of 12) while in four cases (Pinatubo/Cerro Hudson, Agung, Kakatoa, and Reclus) the values are lower than the 25 th percentile and in one case (Cosiguina) we found a value larger than the 75th percentile.

The reported results show a considerable variability with relative standard deviations of the volcanic fluxes ranging from $33 \%$ to $65 \%$ for all the known signatures. By looking at a more regional scale, including the four cores drilled at GV7 and Talos Dome sites, we observe a different behavior in terms of relative variability. In particular, most of the signatures exhibit a lower data dispersion with standard deviations comprised between 10\% (Tambora) and 50\% (Pinatubo/Cerro Hudson) except for Reclus and Samalas affected by $96 \%$ and $78 \%$ relative standard deviations, respectively. The variability of volcanic fluxes, both at regional and continental scale, can be explained by a number of parameters weighing differently on the different sites [62]: accumulation rate and dominant deposition mechanism (wet/dry) at the drilling site, origin and routes of the air masses delivering the volcanic sulphate, ablation processes operated by wind scouring possibly removing volcanic layers on the snow surface, analytical resolution of the sulphate measurement, methods for the evaluation and subtraction of the biogenic contribution with particular regard to the averaging procedures (temporal/spatial width of the moving window). The observed variability also at regional scale is not something unexpected since a high variability has been already observed even in ice cores drilled at the same site [63,64]. As shown in Figure 4, even in ice cores drilled in the same area, the volcanic eruptions can be recorded as very different signatures in the ice. Figure $4 \mathrm{a}-\mathrm{c}$ show three different eruptions as recorded in TALDICE, TD96, and GV7 ice cores and have been assigned to the signatures of Tambora, Reclus, and Samalas, respectively. While for Tambora (Figure 4a) and Samalas (Figure 4c) the sulphate profiles are similar in terms of maximum sulphate concentration, the eruption of Reclus is recorded in the TD96 ice core with a maximum sulphate concentration 5-fold higher than those recorded at GV7 and TALDICE. 


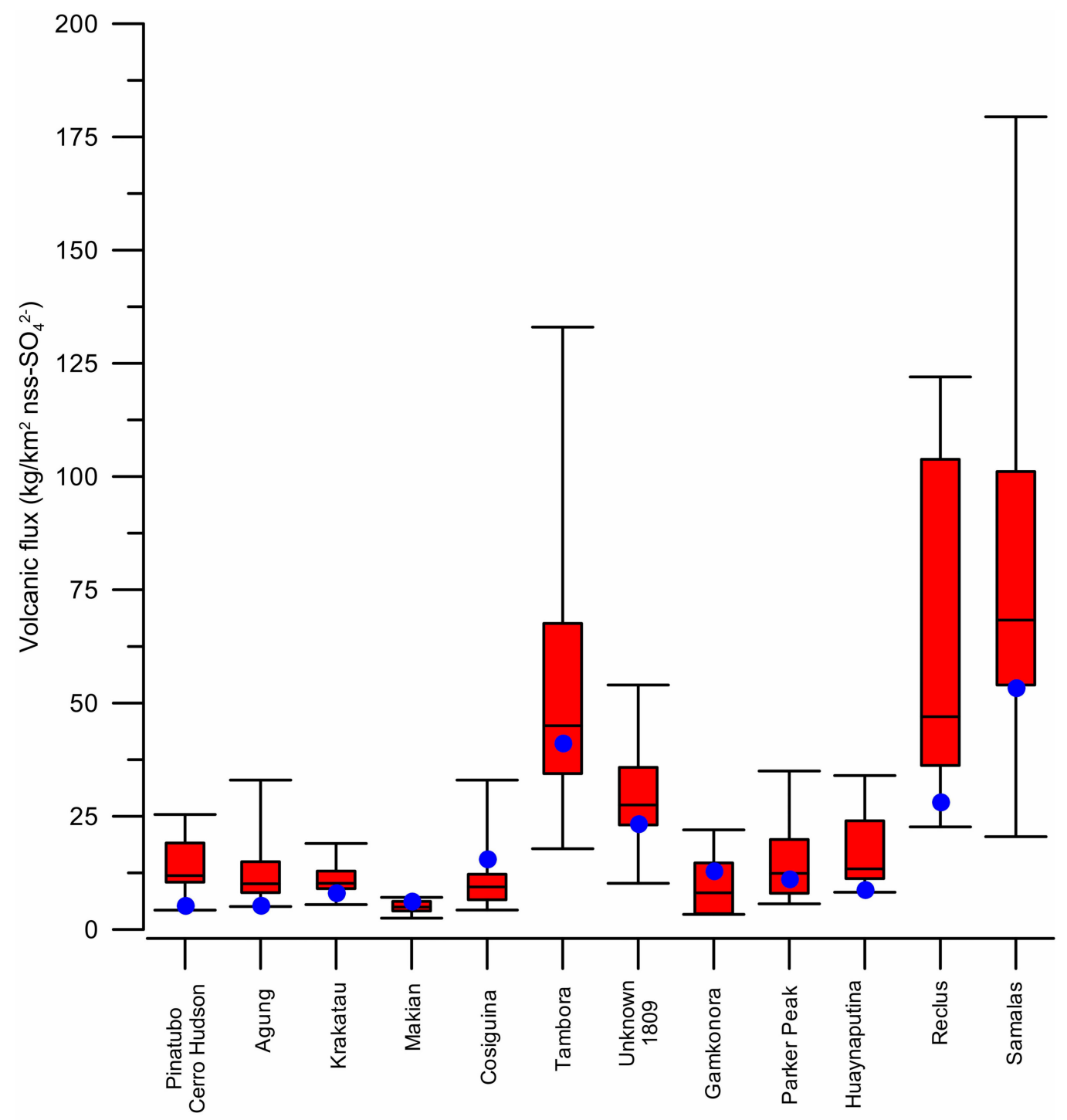

Figure 3. Volcanic fluxes (in $\mathrm{kg} / \mathrm{km}^{2}$ ) of different known volcanic eruptions. The blue dots represent the nss-SO ${ }_{4}^{2-}$ flux as recorded in the GV7 ice core.
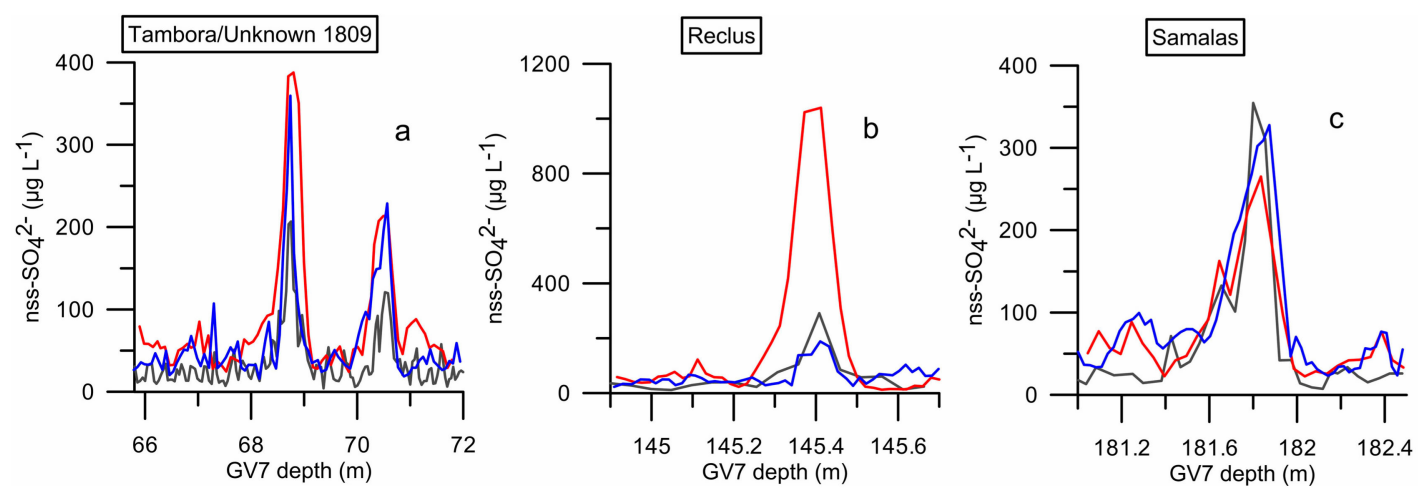

Figure 4. $\mathrm{nsSO}_{4}{ }^{2-}$ profiles as recorded at the time of three major volcanic eruptions: (a) Tambora/Unknown 1809, (b) Reclus, and (c) Samalas. In the figure, the $\mathrm{nsSSO}_{4}{ }^{2-}$ measured at GV7 (dark grey line), TD96 (red line), and TALDICE (blue line) is shown. 
Table 4. Volcanic fluxes $f(\mathrm{~kg} / \mathrm{km} 2)$ of known past volcanic eruptions estimated in GV7 and different sites are reported as comparison, alongside the uncertainty over the evaluation.

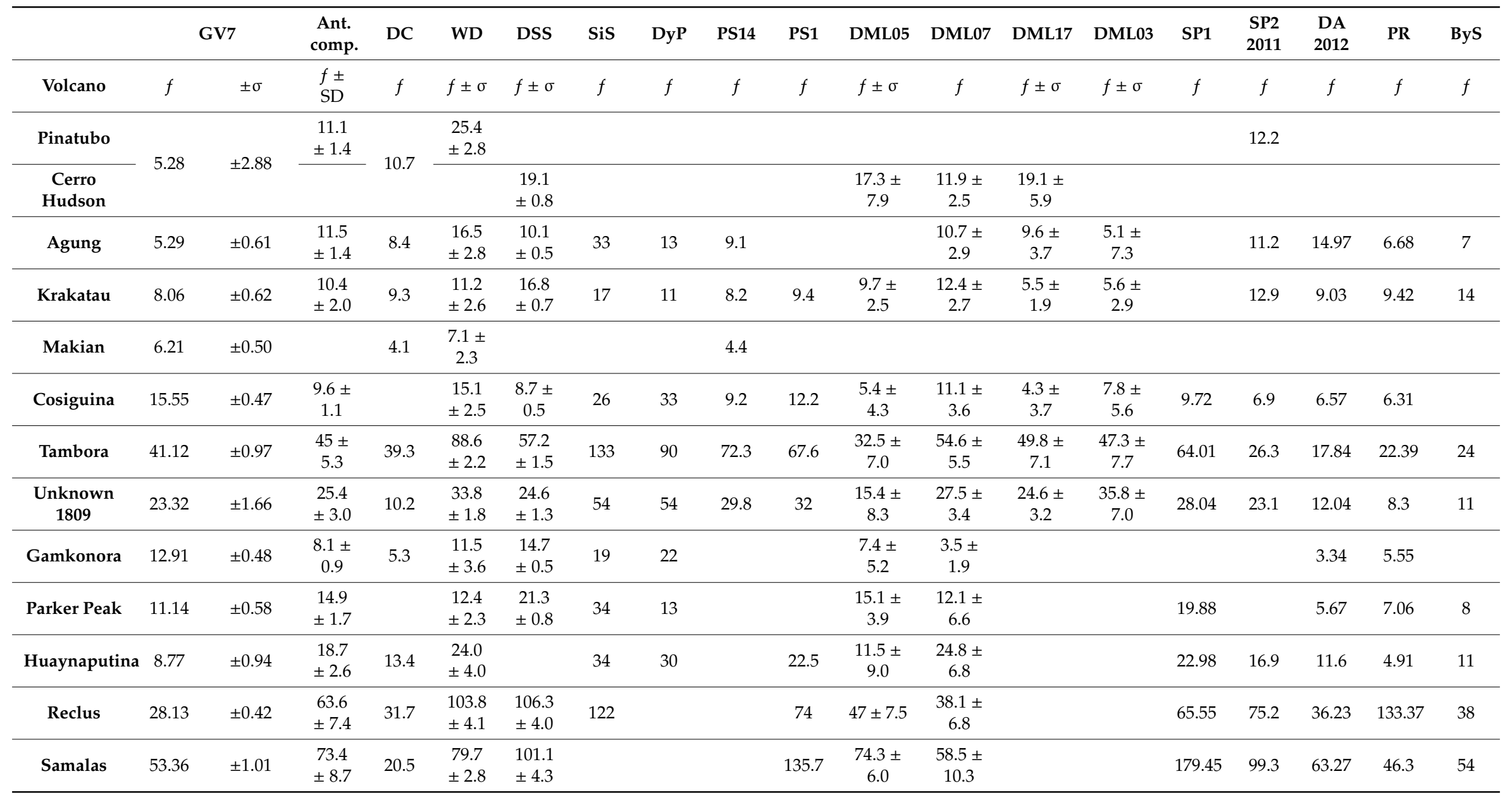




\section{Conclusions}

In this work we reconstructed the deposition fluxes of volcanic sulphate of the major eruptions that occurred in the last millennium from the coastal Antarctic GV7 ice core (Northern Victoria Land).

We calculated the background biogenic contribution, following two different methods, and removed this from the total non-sea salt sulphate $\left(\mathrm{nssSO}_{4}{ }^{2-}\right)$ budget. The results were compared with previously published estimates of volcanic depositions over the entire Antarctic continent. In general, we obtained comparable or lower values with respect to the most comprehensive composite record to date by Sigl et al. [34]. By taking into account all the available datasets from single ice cores, the comparison of the volcanic fluxes highlights that our values are not significantly different from the other estimations considering the overall variability. At a regional scale we compared our record with three other ice cores drilled in sites close by (Talos Dome and a previous GV7 ice core) and we observed an inter-site variability of the same order of magnitude. The new dataset can represent a useful tool for the improvement of climatic models which take into account the volcanic forcing on the Earth's radiative budget.

Moreover, this paper is a key tool for the construction of an annually counted age scale for the GV7 high resolution ice core record. The identification of 24 volcanic signatures and a tephra layer (Mount Rittmann) is a milestone for the correction of annual layer counting errors and will greatly help in building an accurate age-scale for this ice core.

Supplementary Materials: The following are available online at http://www.mdpi.com/2076-3263/10/1/38/s1, Figure S1: Depth vs. Age curve according to the preliminary dating of the core, Table S1: Evaluation of the analytical method performances, Table S2: Comparison of the $\mathrm{SO}_{4}{ }^{2-}$ concentration at GV7 and at Dome C.

Author Contributions: Conceptualization, M.S. and R.T.; Data curation, R.N., L.C., M.F., M.S., and R.T.; Formal analysis, R.N., A.A., and L.C.; Investigation, M.S. and R.T.; Methodology, M.S. and R.T.; Supervision, S.B., M.S., and R.T.; Visualization, R.N.; Writing-original draft, R.N., S.B., M.S., and R.T.; Writing—review and editing, M.F., M.S., B.S., and R.T. All authors have read and agreed to the published version of the manuscript.

Acknowledgments: This research was financially supported by the MIUR (Italian Ministry of University and Research)-PNRA (Italian Antarctic Research Program) program through the IPICS-2kyr-It project (International Partnership for Ice Core Science, reconstructing the climate variability for the last $2 \mathrm{kyr}$, the Italian contribution). The IPICS-2kyr-It project is carried out in cooperation with KOPRI (Korea Polar Research Institute, grant No. PE15010). The fellowship personnel involved the analysis of the GV7 core and the laboratory equipment was partially funded by Fondazione Cassa di Risparmio di Firenze, MIUR-PNRA “BE-OI" (PNRA16_00124) and "3D" (PNRA16_00212) projects and MIUR-PRIN 2017 "AMICO". We appreciate the feedback of the two anonymous reviewers, which greatly helped to clarify and improve the manuscript.

Conflicts of Interest: The authors declare no conflict of interest.

\section{References}

1. Zielinski, G.A. Use of paleo-records in determining variability within the volcanism-climate system. Quat. Sci. Rev. 2000, 19, 417-438. [CrossRef]

2. Robock, A. Volcanic eruptions and climate. Rev. Geophys. 2000, 38, 191-219. [CrossRef]

3. Zanchettin, D.; Khodri, M.; Timmreck, C.; Toohey, M.; Schmidt, A.; Gerber, E.P.; Hegerl, G.; Robock, A.; Pausata, F.S.R.; Ball, W.T.; et al. The Model Intercomparison Project on the climatic response to Volcanic forcing (VolMIP): Experimental design and forcing input data for CMIP6. Geosci. Model Dev. 2016, 9, 2701-2719. [CrossRef]

4. Sigurdsson, H. Evidence of volcanic loading of the atmosphere and climate response. Glob. Planet. Chang. 1990, 3, 277-289. [CrossRef]

5. Kremser, S.; Thomason, L.W.; von Hobe, M.; Hermann, M.; Deshler, T.; Timmreck, C.; Toohey, M.; Stenke, A.; Schwarz, J.P.; Weigel, R.; et al. Stratospheric aerosol-observations, processes, and impact on climate. Rev. Geophys. 2016, 54, 278-335. [CrossRef]

6. Yue, G.K. The Formation and Growth of Sulphate Aerosol in the Stratosphere. Atmos. Environ. 1981, 15, 549-556. [CrossRef]

7. Rampino, M.R.; Self, S. Historic Eruptions of Tambora (1815), Krakatau (1883), and Agung (1963), Their Stratospheric Aerosol, and Climatic Impact. Quat. Res. 1982, 18, 127-143. [CrossRef] 
8. Delmas, R.J.; Legrand, M.; Aristarain, A.J.; Zanolini, F. Volcanic deposits in Antarctic snow and ice. J. Geophys. Res. Atmos. 1985, 90, 12901-12920. [CrossRef]

9. Hammer, C.U. Acidity of Polar Ice Cores in Relation to Absolute Dating, Past Volcanism, and Radio-Echoes. J. Glaciol. 1980, 25, 359-372. [CrossRef]

10. Hammer, C.U.; Clausen, H.B.; Tauber, H. Ice-Core Dating of the Pleistocene/Holocene Boundary Applied to a Calibration of the 14C Time Scale. Radiocarbon 1986, 28, 284-291. [CrossRef]

11. Hammer, C.U.; Clausen, H.B.; Dansgaard, W. Greenland ice sheet evidence of post-glacial volcanism and its climatic impact. Nature 1980, 288, 230-235. [CrossRef]

12. Zielinski, G.A.; Mayewski, P.A.; Meeker, L.D.; Whitlow, S.; Twickler, M.S. A 110,000-Yr Record of Explosive Volcanism from the GISP2 (Greenland) Ice Core. Quat. Res. 1996, 45, 109-118. [CrossRef]

13. Zielinski, G.A.; Mayewski, P.A.; Meeker, L.D.; Whitlow, S.; Twickler, M.S.; Morrison, M.; Meese, D.A.; Gow, A.J.; Alley, R.B. Record of Volcanism Since 7000 B.C. from the GISP2 Greenland Ice Core and Implications for the Volcano-Climate System. Science 1994, 264, 948-952. [CrossRef] [PubMed]

14. Cole-Dai, J.; Budner, D.M.; Ferris, D.G. High speed, high resolution, and continuous chemical analysis of ice cores using a melter and ion chromatography. Environ. Sci. Technol. 2006, 40, 6764-6769. [CrossRef]

15. Severi, M.; Becagli, S.; Traversi, R.; Udisti, R. Recovering paleo-records from Antarctic ice-cores by coupling a continuous melting device and fast ion chromatography. Anal. Chem. 2015, 87, 11441-11447. [CrossRef]

16. McConnell, J.R.; Lamorey, G.W.; Lambert, S.W.; Taylor, K.C. Continuous ice-core chemical analyses using inductively coupled plasma mass spectrometry. Environ. Sci. Technol. 2002, 36, 7-11. [CrossRef]

17. Frezzotti, M.; Urbini, S.; Proposito, M.; Scarchilli, C.; Gandolfi, S. Spatial and temporal variability of surface mass balance near Talos Dome, East Antarctica. J. Geophys. Res. Earth Surf. 2007, 112. [CrossRef]

18. Stenni, B.; Proposito, M.; Gragnani, R.; Flora, O.; Jouzel, J.; Falourd, S.; Frezzotti, M. Eight centuries of volcanic signal and climate change at Talos Dome (East Antarctica). J. Geophys. Res. Atmos. 2002, 107. [CrossRef]

19. Magand, O.; Frezzotti, M.; Pourchet, M.; Stenni, B.; Genoni, L.; Fily, M. Climate variability along latitudinal and longitudinal transects in East Antarctica. Ann. Glaciol. 2004, 39, 351-358. [CrossRef]

20. Caiazzo, L.; Baccolo, G.; Barbante, C.; Becagli, S.; Bertò, M.; Ciardini, V.; Crotti, I.; Delmonte, B.; Dreossi, G.; Frezzotti, M.; et al. Prominent features in isotopic, chemical and dust stratigraphies from coastal East Antarctic ice sheet (Eastern Wilkes Land). Chemosphere 2017, 176, 273-287. [CrossRef]

21. Morganti, A.; Becagli, S.; Castellano, E.; Severi, M.; Traversi, R.; Udisti, R. An improved flow analysis-ion chromatography method for determination of cationic and anionic species at trace levels in Antarctic ice cores. Anal. Chim. Acta 2007, 603, 190-198. [CrossRef] [PubMed]

22. Caiazzo, L.; Becagli, S.; Frosini, D.; Giardi, F.; Severi, M.; Traversi, R.; Udisti, R. Spatial and temporal variability of snow chemical composition and accumulation rate at Talos Dome site (East Antarctica). Sci. Total Environ. 2016, 550, 418-430. [CrossRef] [PubMed]

23. Prospero, J.M.; Savoie, D.L.; Saltzman, E.S.; Larsen, R. Impact of oceanic sources of biogenic sulphur on sulphate aerosol concentrations at Mawson, Antarctica. Nature 1991, 350, 221-223. [CrossRef]

24. Legrand Michel, M.P. Glaciochemistry of polar ice cores: A review. Rev. Geophy. 1997, 35, 219-243. [CrossRef]

25. Becagli, S.; Proposito, M.; Benassai, S.; Flora, O.; Genoni, L.; Gragnani, R.; Largiuni, O.; Pili, S.L.; Severi, M.; Stenni, B.; et al. Chemical and isotopic snow variability in East Antarctica along the 2001/02 ITASE traverse. Ann. Glaciol. 2004, 39, 473-482. [CrossRef]

26. Castellano, E.; Becagli, S.; Hansson, M.; Hutterli, M.; Petit, J.R.; Rampino, M.R.; Severi, M.; Steffensen, J.P.; Traversi, R.; Udisti, R. Holocene volcanic history as recorded in the sulfate stratigraphy of the European Project for Ice Coring in Antarctica Dome C (EDC96) ice core. J. Geophys. Res. Atmos. 2005, 110. [CrossRef]

27. Castellano, E.; Becagli, S.; Jouzel, J.; Migliori, A.; Severi, M.; Steffensen, J.P.; Traversi, R.; Udisti, R. Volcanic eruption frequency over the last $45 \mathrm{ky}$ as recorded in Epica-Dome C ice core (East Antarctica) and its relationship with climatic changes. Glob. Planet. Chang. 2004, 42, 195-205. [CrossRef]

28. Cole-Dai, J.; Mosley-Thompson, E. The Pinatubo eruption in South Pole snow and its potential value to ice-core paleovolcanic records. Ann. Glaciol. 1999, 29, 99-105. [CrossRef]

29. Traufetter, F.; Oerter, H.; Fischer, H.; Weller, R.; Miller, H. Spatio-temporal variability in volcanic sulphate deposition over the past $2 \mathrm{kyr}$ in snow pits and firn cores from Amundsenisen, Antarctica. J. Glaciol. 2004, 50, 137-146. [CrossRef] 
30. Sigl, M.; McConnell, J.R.; Layman, L.; Maselli, O.; McGwire, K.; Pasteris, D.; Dahl-Jensen, D.; Steffensen, J.P.; Vinther, B.; Edwards, R.; et al. A new bipolar ice core record of volcanism from WAIS Divide and NEEM and implications for climate forcing of the last 2000 years. J. Geophys. Res. Atmos. 2013, 118, 1151-1169. [CrossRef]

31. Severi, M.; Becagli, S.; Castellano, E.; Morganti, A.; Traversi, R.; Udisti, R.; Rüth, U.; Fischer, H.; Huybrechts, P.; Wolff, E.; et al. Synchronisation of the EDML and EDC ice cores for the last $52 \mathrm{kyr}$ by volcanic signature matching. Clim. Past 2007, 3, 367-374. [CrossRef]

32. Severi, M.; Udisti, R.; Becagli, S.; Stenni, B.; Traversi, R. Volcanic synchronisation of the EPICA-DC and TALDICE ice cores for the last 42 kyr BP. Clim. Past 2012, 8, 509-517. [CrossRef]

33. Simkin, T.; Siebert, L. Volcanoes of the World, 2nd ed.; Geoscience Press: Tucson, AZ, USA, 1994.

34. Sigl, M.; Winstrup, M.; McConnell, J.R.; Welten, K.C.; Plunkett, G.; Ludlow, F.; Büntgen, U.; Caffee, M.; Chellman, N.; Dahl-Jensen, D.; et al. Timing and climate forcing of volcanic eruptions for the past 2500 years. Nature 2015, 523, 543-549. [CrossRef] [PubMed]

35. Sigl, M.; McConnell, J.R.; Toohey, M.; Curran, M.; Das, S.B.; Edwards, R.; Isaksson, E.; Kawamura, K.; Kipfstuhl, S.; Krüger, K.; et al. Insights from Antarctica on volcanic forcing during the Common Era. Nat. Clim. Chang. 2014, 4, 693-697. [CrossRef]

36. Proposito, M.; Frezzotti, M. Preliminary glacio-chemical analysis of GV5 and GV7 firn cores collected along the Oates Coast-Talos Dome Transect. Terra Antarct. Rep. 2008, 14, 111-116.

37. Cacciani, M.; Di Girolamo, P.; Di Sarra, A.; Fiocco, G.; Fuà, D. Volcanic aerosol layers observed by lidar at South Pole, September 1991-June 1992. Geophys. Res. Lett. 1993, 20, 807-810. [CrossRef]

38. Deshler, T.; Adriani, A.; Gobbi, G.P.; Hofmann, D.J.; Di Donfrancesco, G.; Johnson, B.J. Volcanic aerosol and ozone depletion within the Antarctic polar vortex during the austral spring of 1991. Geophys. Res. Lett. 1992, 19, 1819-1822. [CrossRef]

39. Cole-Dai, J.; Mosley-Thompson, E.; Thompson, L.G. Quantifying the Pinatubo volcanic signal in south polar snow. Geophys. Res. Lett. 1997, 24, 2679-2682. [CrossRef]

40. Traversi, R.; Becagli, S.; Castellano, E.; Cerri, O.; Morganti, A.; Severi, M.; Udisti, R. Study of Dome C site (East Antartica) variability by comparing chemical stratigraphies. Microchem. J. 2009, 92, 7-14. [CrossRef]

41. Severi, M.; Becagli, S.; Castellano, E.; Morganti, A.; Traversi, R.; Udisti, R. Thirty years of snow deposition at Talos Dome (Northern Victoria Land, East Antarctica): Chemical profiles and climatic implications. Microchem. J. 2009, 92, 15-20. [CrossRef]

42. Moore, J.C.; Narita, H.; Maeno, N. A continuous 770-year record of volcanic activity from east Antarctica. J. Geophys. Res. Atmos. 1991, 96, 17353-17359. [CrossRef]

43. Dai, J.; Mosley-Thompson, E.; Thompson, L.G. Ice core evidence for an explosive tropical volcanic eruption 6 years preceding Tambora. J. Geophys. Res. Atmos. 1991, 96, 17361-17366. [CrossRef]

44. Yalcin, K.; Wake, C.P.; Kreutz, K.J.; Germani, M.S.; Whitlow, S.I. Ice core evidence for a second volcanic eruption around 1809 in the Northern Hemisphere. Geophys. Res. Lett. 2006, 33. [CrossRef]

45. Hartman, L.H.; Kurbatov, A.V.; Winski, D.A.; Cruz-Uribe, A.M.; Davies, S.M.; Dunbar, N.W.; Iverson, N.A.; Aydin, M.; Fegyveresi, J.M.; Ferris, D.G.; et al. Volcanic glass properties from 1459 C.E. volcanic event in South Pole ice core dismiss Kuwae caldera as a potential source. Sci. Rep. 2019, 9, 14437. [CrossRef]

46. Narcisi, B.; Petit, J.R.; Delmonte, B.; Batanova, V.; Savarino, J. Multiple sources for tephra from AD 1259 volcanic signal in Antarctic ice cores. Quat. Sci. Rev. 2019, 210, 164-174. [CrossRef]

47. Narcisi, B.; Proposito, M.; Frezzotti, M. Ice record of a 13thcentury explosive volcanic eruption in northern Victoria Land, East Antarctica. Antarct. Sci. 2001, 13, 174-181. [CrossRef]

48. Di Roberto, A.; Colizza, E.; Del Carlo, P.; Petrelli, M.; Finocchiaro, F.; Kuhn, G. First marine cryptotephra in Antarctica found in sediments of the western Ross Sea correlates with englacial tephras and climate records. Sci. Rep. 2019, 9, 10628. [CrossRef]

49. Lee, M.J.; Kyle, P.R.; Iverson, N.A.; Lee, J.I.; Han, Y. Rittmann volcano, Antarctica as the source of a widespread $1252 \pm 2$ CE tephra layer in Antarctica ice. Earth Planet. Sci. Lett. 2019, 521, 169-176. [CrossRef]

50. Newhall, C.G.; Self, S. The volcanic explosivity index (VEI) an estimate of explosive magnitude for historical volcanism. J. Geophys. Res. Oceans 1982, 87, 1231-1238. [CrossRef]

51. Lamb, H.H. Volcanic Dust in the Atmosphere; with a Chronology and Assessment of Its Meteorological Significance. Philos. Trans. R. Soc. Lond. Ser. A Math. Phys. Eng. Sci. 1970, 266, 425-533. [CrossRef] 
52. Koffman, B.G.; Dowd, E.G.; Osterberg, E.C.; Ferris, D.G.; Hartman, L.H.; Wheatley, S.D.; Kurbatov, A.V.; Wong, G.J.; Markle, B.R.; Dunbar, N.W.; et al. Rapid transport of ash and sulfate from the 2011 Puyehue-Cordón Caulle (Chile) eruption to West Antarctica. J. Geophys. Res. Atmos. 2017, 122, 8908-8920. [CrossRef]

53. Dunbar, N.W.; Iverson, N.A.; Van Eaton, A.R.; Sigl, M.; Alloway, B.V.; Kurbatov, A.V.; Mastin, L.G.; McConnell, J.R.; Wilson, C.J.N. New Zealand supereruption provides time marker for the Last Glacial Maximum in Antarctica. Sci. Rep. 2017, 7, 12238. [CrossRef] [PubMed]

54. Plummer, C.T.; Curran, M.A.J.; Van Ommen, T.D.; Rasmussen, S.O.; Moy, A.D.; Vance, T.R.; Clausen, H.B.; Vinther, B.M.; Mayewski, P.A. An independently dated 2000-yr volcanic record from Law Dome, East Antarctica, including a new perspective on the dating of the 1450s CE eruption of Kuwae, Vanuatu. Clim. Past 2012, 8, 1929-1940. [CrossRef]

55. Cole-Dai, J.; Mosley-Thompson, E.; Thompson, L.G. Annually resolved southern hemisphere volcanic history from two Antarctic ice cores. J. Geophys. Res. Atmos. 1997, 102, 16761-16771. [CrossRef]

56. Delmas, R.J.; Kirchner, S.; Palais, J.M.; Petit, J.R. 1000 years of explosive volcanism recorded at the South Pole. Tellus B 1992, 44, 335-350. [CrossRef]

57. Budner, D.; Cole-Dai, J. The number and magnitude of large explosive volcanic eruptions between 904 and 1865 A.D.: Quantitative evidence from a new South Pole ice core. In Volcanism and the Earth's Atmosphere; Geophysical Monograph Series; American Geophysical Union: Washington, DC, USA, 2003; Volume 139, pp. 165-176.

58. Ferris, D.G.; Cole-Dai, J.; Reyes, A.R.; Budner, D.M. South Pole ice core record of explosive volcanic eruptions in the first and second millennia A.D. and evidence of a large eruption in the tropics around 535 A.D. J. Geophys. Res. Atmos. 2011, 116. [CrossRef]

59. Jiang, S.; Cole-Dai, J.; Li, Y.; Ferris, D.G.; Ma, H.; An, C.; Shi, G.; Sun, B. A detailed 2840 year record of explosive volcanism in a shallow ice core from Dome A, East Antarctica. J. Glaciol. 2012, 58, 65-75. [CrossRef]

60. Cole-Dai, J.; Mosley-Thompson, E.; Wight, S.P.; Thompson, L.G. A 4100-year record of explosive volcanism from an East Antarctica ice core. J. Geophys. Res. Atmos. 2000, 105, 24431-24441. [CrossRef]

61. Langway, C.C., Jr.; Osada, K.; Clausen, H.B.; Hammer, C.U.; Shoji, H.; Mitani, A. New chemical stratigraphy over the last millennium for Byrd Station, Antarctica. Tellus B Chem. Phys. Meteorol. 1994, 46, 40-51. [CrossRef]

62. Toohey, M.; Krüger, K.; Timmreck, C. Volcanic sulfate deposition to Greenland and Antarctica: A modeling sensitivity study. J. Geophys. Res. Atmos. 2013, 118, 4788-4800. [CrossRef]

63. Wolff, E.W.; Cook, E.; Barnes, P.R.; Mulvaney, R. Signal variability in replicate ice cores. J. Glaciol. 2005, 51, 462-468. [CrossRef]

64. Gautier, E.; Savarino, J.; Erbland, J.; Lanciki, A.; Possenti, P. Variability of sulfate signal in ice core records based on five replicate cores. Clim. Past 2016, 12, 103-113. [CrossRef]

(C) 2020 by the authors. Licensee MDPI, Basel, Switzerland. This article is an open access article distributed under the terms and conditions of the Creative Commons Attribution (CC BY) license (http://creativecommons.org/licenses/by/4.0/). 